\title{
Menumbuhkan Kesadaran Berzakat Pada Masyarakat Di Wilayah Mega Kuningan Jakarta
}

\author{
Tatik Mariyanti ${ }^{1 *}$, Edy Aswandi $^{2}$, Primasatria Edastama $^{3}$, Mayangsari Edastami ${ }^{4}$ \\ ${ }^{1}$ Fakultas Ekonomi dan Bisnis Universitas Trisakti \\ ${ }^{2,3,4}$ Fakultas Ekonomi dan Bisnis Universitas Esa Unggul \\ *e-mail: tatik_m2002@yahoo.com
}

Informasi Artikel

Diterima Redaksi : 11 Agustus 2020

Revisi Akhir : 23 September 2020

Diterbitkan Online : 26 Oktober 2020

\section{PENDAHULUAN}

Panduan ini berisikan penjelasan mengenai tata tulis untuk artikel ilmiah Jurnal Pengabdian Barelang (JPB). Panduan ini harus diperhatikan oleh seluruh penulis yang akan mempublikasikan atau menerbitkan artikel ilmiah dari hasil kegiatan Pengabdian Kepada Masyarakat (PKM). Topik artikel yang diusulkan harus sesuai dengan topik yang ditentukan oleh redaksi pada setiap

Indonesia merupakan negara terbesar penduduknya ke empat setelah, China, India dan Amerika Serikat dengan jumlah penduduk sebesar 270 juta jiwa, data yang dikeluarkan oleh The world Bank [1]. Penduduk Indonesia mayoritas adalah beragama Islam menurut data dari Komisi A.S. untuk Kebebasan Beragama Internasional, USCIRF sebanyak $87 \%$ dari total populasi penduduk Indonesia [2]. Agama Islam mengajarkan betapa pentingnya berbagi dengan sesama terutama zakat. Zakat merupakan penganalogian dengan bentuk pengenaan pajak agama [3].

\section{Abstrak}

Penelitian ini bertujuan untuk menumbuhkan kesadaran masyarakat di lingkungan kampus Universitas Trisakti Mega Kuningan tentang pentingnya membayar zakat. Potensi pendapatan zakat di Indonesia sangat besar dan realisasinya masih sedikit dari potensi yang ada, sehingga perlu ada kajian dan mengenai hal ini. Penelitian ini dalam bentuk pelaksanaan pengabdian kepada masyarakat yaitu dengan memberikan sosialisasi dan edukasi, dengan metode analisis deskriptif. Peneliti melakukan pengamatan langsung, sekaligus menjadi pembicara dan nara sumber. Data yang didapat dikumpulkan dan dianalisis dengan teori dan penelitian sebelumnya. Sosialisasi dan edukasi yang dilakukan oleh tim PKM dari Universitas Trisakti dan Universitas Esa Unggul dapat menumbuhkan kesadaran masyarakat untuk berzakat. Hal tersebut sejalan dengan penelitian terdahulu dan teori yang ada bahwa sosialisasi dan edukasi sangat diperlukan untuk dapat menumbuhkan kesadaran masyarakat dalam berzakat. Pada masa yang akan datang perlu ada model pelatihan khusus mengenai zakat kepada masyarakat.

Zakat merupkan refleksi seorang muslim dimana dalam hidupnya ada harta yang bukan miliknya, atau hak orang lain yang membutuhkannya. Manusia adalah mahluk sosial yang selalu membutuhkan bantuan orang lain, karena menjalani hidup sudah dibantu orang lain, maka ada kewajiban juga untuk memberi bantuan kepada orang lain, salah satunya adalah dengan berzakat. Zakat merupakan bentuk tanggung jawab seorang muslim terhadap agamanya dan kehidupan bersosial.

Potensi zakat di Indonesia sangat besar yaitu sekitar 217 triliyun rupiah [4], potensi yang besar ini apabila dapat terealisasi maka bisa dibayangkan betapa besar penerimaan pendapatan negara dari sektor zakat. Sektor zakat dan pajak jika digabungkan maka dapat dibayangkan berapa banyak pendapatan negara yang akan diterima dan kemiskinan di negara Indonesia akan berkurang. Potensi ini seharusnya dapat terealisasi, peran semua komponen bangsa dalam sosialisasi dan edukasi mengenai zakat terus dilakukan secara 
berkesinambungan agar kesadaran untuk berzakat dapat tumbuh pada masyarakat. Hal tersebut yang menjadikan Islamic Economics and Finance Universitas Trisakti melakukan sosialisasi zakat kepada masyarakat di lingkungan Kampus Mega Kuningan, Universitas Trisakti. Pentingnya sosialisasi dan edukasi mengenai zakat ini, merupakan wujud nyata bagi tridarma perguruan tinggi untuk pengabdian kepada masyarakat (PKM). Kegiatan pengabdian kepada masyarakat ini dilakukan dilingkungan kampus Universitas Trisakti karena kepedulian akan masyarakat sekitar, karena kepedulian dimulai dari masyarakat sekitar atau pada entitas terdekat baru melangkah pada masyarakat luas. Pada masyarakat luas dengan skala nasional juga sudah dilakukan dengan mengadakan seminar nasional mengenai zakat.

Lingkungan kampus Mega Kuningan terdapat lembaga pedidikan Al-Mughni dimana lembaga pendidikan tersebut menampung dan memberikan pendidikan kepada anak yatim untuk dapat bersekolah dan mengenyam pendidikan hingga perguruan tinggi. lembaga pendidikan ini juga menerima santunan, sedekah dan zakat untuk dapat di distribusikan kepada yang membutuhkannya. Keberadaan lembaga AlMughni sangat dibutuhkan karena masih sedikit lembaga pendidikan yang peduli dengan anak yatim. Anak yatim yang ditampung dan disekolahkan juga merupakan anak-anak yang berprestasi.

\section{METODE}

Penelitian ini menggunakan metode survey dengan melakukan observasi langsung kepada objek penelitian dan nantinya data yang didapat akan dikumpulkan dan dianalisis dengan teori dan penelitian terdahulu yang berkaitan dengan penelitian ini. Peneliti langsung melakukan pengamatan dan melihat pemahaman yang ada pada responden, dengan mengumpulkan data-data yang didapat dalam pengamatan langsung kepada responden [5]. Berkaitan dengan responden bisa meliputi individu, perorangan, rumah tangga, komunitas dari social atau sesuatu hal yang menarik untuk diteliti [6].

Penelitian ini melakukan kegiatan pengabdian kepada masyarakat (PKM) dengan melakukan sosialisasi dan edukasi yang berkaitan dengan zakat. Responden yang ada adalah para masyarakat yang tinggal di lingkungan kampus Mega Kuningan Universitas Trisakti. Para responden yang hadir paling dominan adalah dari lembaga Pendidikan Al-Mughni, dimana banyak terdapat anak-anak usia sekolah dan remaja. Responden yang ada merupakan objek penelitian yang diharapkan dengan adanya kegiatan pengabdian kepada masyarakat, sosialisasi dan edukasi mengenai zakat dapat dipahami oleh masyarakat sekitar lingkungan kampus Universitas Trisakti di Mega Kuningan Jakarta.

Peneliti pada penelitian ini juga menjadi pembicara dalam kegiatan PKM sosialisasi dan edukasi zakat. Keterlibatan langsung peneliti dari kegiatan ini dengan mengamati para peserta dan hasil pengamatan dikumpulkan, data yang didapat yang nantinya dianalisis dengan menggunakan teori dan penelitian terdahulu. Penelitian ini tergolong penelitian kualitatf deskriptif, karena pembahasan hasil penelitian didapat dari menganalisis dengan teori dan kajian literatur yang ada [7].

Kontribusi peneliti pada penelitian ini dengan melakukan kegiatan PKM sebagai pembicara dengan topik mengenai zakat. Hasil akhirnya adalah agar para peserta PKM dapat lebih memahami zakat. Pemahaman yang didapat dari para peserta diharapkan nantinya dapat meningkatkan realisasi pendapatan zakat dari potensinya yang ada. Pemahaman akan sesuatu tersebut khususnya adalah zakat, dengan adanya sosialisasi dan edukasi ini, para masyarakat mendapat pengetahuan yang baru yang nantinya akan merubah sikap para peserta [8]. Perubahan sikap peserta PKM terhadap pembayaran zakat dikarenakan adanya dorongan yang kuat dan motivasi untuk membayar zakat.

\section{HASIL DAN PEMBAHASAN}

Zakat itu sendiri adalah merupakan salah satu rukun Islam yang berkaitan dengan sosial dan keuangan, sebagai bentuk kewajiban seorang muslim terhadap agamanya [9]. Islam benar-benar mengatur mengenai keuangan dan kehidupan sosial manusia, zakat itulah refleksi dari seorang muslim yang konsern dengan harta dan kehidupan sosialnya. Zakat juga bukan 
merupakan pajak transaksional seperti pajak pertambahan nilai misalnya [10]. Definisi zakat juga berbeda dengan pajak yang ada sekarang ini.

Zakat merupakan bentuk kewajiban akan harta yang dimilikinya untuk kehidupan sosialnya. Dana zakat juga bisa dijadikan alternatif dan pendukung utama untuk mengentaskan kemiskinan, peran serta masyarakat diharapkan dapat membantu mengumpulkan dan menyalurkan zakat untuk mengentaskan kemiskinan [11]. Betapa pentingnya sosialisasi dan edukasi bagi masyarakat muslim mengenai zakat ini. Perintah zakat sangat jelas dalam kitab suci agama Islam yaitu seorang muslim berkewajiban dalam membayar zakat. Semua muslim harus memiliki kepedulian akan hal ini, karena perintah membayar zakat adalah perintah agama untuk membantu sesama muslim, dimana umat muslim yang kekurangan dan miskin dapat dibantu karena adanya zakat ini.

Pembayaran zakat harus sesuai dengan ambang batasnya atau sesuai nisabnya dan setiap nisab berbeda-beda sesuai dengan harta atau asset yang dimiliki [12]. Nisab atau ambang batas zakat sudah ditentukan oleh Al-Quran dan juga telah ditentukan oleh para ulama muslim dan sudah disesuaikan dengan perkembangan zaman. Keberagaman akan zakat yang ada sekarang ini, merupakan hasil dari pemikiran atau ijtihad dari para ulama muslim. Pengumpulan zakat dengan berbagai jenis zakat sesuai dengan nisabnya akan menghasilkan kemaslahatan dan kebermanfaatan bagi umat muslim ataupun bagi umat lainnya [13]. Potensi zakat yang besar ini bila terealisasi maka akan berdampak besar bagi pengentasan kemiskinan di Indonesia. Penyadaran akan zakat terutama pada masyarakat dilingkungan kampus Mega Kuningan Universitas Trisakti sangat diharapkan, karena ini akan menjadi multiple efek juga bagi perekonomian bangsa. Pada penelitian sebelumnya yaitu mengatakan bahwa faktor yang mempengaruhi seseorang bisnisman atau pengusaha untuk membayar zakat adalah adanya pemahaman akan pengetahuan zakat itu sendiri [14].

Pengetahuan dan informasi yang dimiliki pengusaha dapat mempengaruhi sikap dan perilaku dalam membayar zakat.
Pengetahuan dan informasi yang dimiliki didapatkan dari sosialisasi ataupun mencari tahu sendiri informasi mengenai zakat, sehingga timbul kesadaran pentingnya berzakat bagi kehidupan sosial seorang muslim. Pengetahuan, informasi dan edukasi merupakan hal yang dapat mempengaruhi sumber daya manusia menjadi lebih berkualitas dan memiliki amanah dan kompetensi dibidang kewirahusahaan, sehingga dapat mengembangkan usaha kecil dan menengah yang pada akhirnya dapat mendukung pendanaan seperti zakat, sedekah dan wakaf [15].

Pengelolaan dana zakat, dari mulai mengumpulkan dan mendistribusikannya kepada yang berhak menerimanya haruslah transparan dan akuntanbilitas, karena hal tersebut adalah terkait dengan kepercayaan masyarakat terhadap suatau lembaga yang mengelola dana zakat. Dana zakat yang dikelola dengan baik dan transparan, akan menimbulkan trust atau kepercayaan sehingga muncul juga kesadaran masyarakat untuk membayar zakat pada lembaga zakat, dengan demikian maka potensi zakat yang ada dapat terealisasikan [16]. Sosialisasi dan edukasi mengenai pengelolaan dana zakat yang baik dan transparan juga sangat diperlukan.

Pada kajian penelitian mengenai model kepribadian yang Islami adalah dimana seorang muslim memiliki model kepribadian yang meliputi diantaranya adalah memiliki ilmu atau pengetahuan, melakukan ibadah dengan benar serta selalu mentaati perintah dalam kitab suci yaitu al-quran [17]. Pengetahuan dan ilmu yang dimiliki adalah merupakan dasar manusia untuk dapat melakukan ibadah dengan benar karena memiliki kesadaran bahwa umat muslim memiliki petunjuk dari kitab sucinya untuk dipatuhi, semua hal itu berkaitan satu sama lainnya.

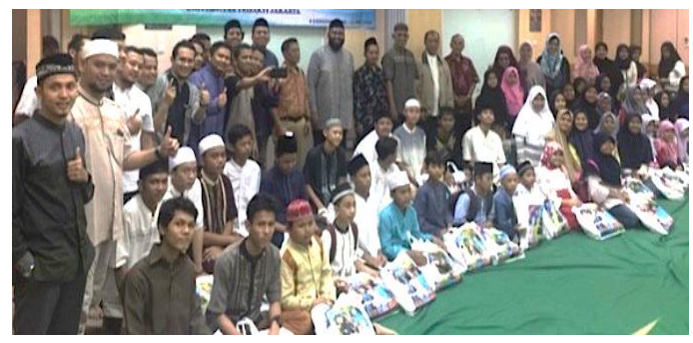

Gambar 1. PKM Zakat Mega Kuningan 
Membayar zakat adalah salah satu perintah yang ada dalam al-quran yang harus dan wajib dipatuhi oleh umat muslim dan hal itu juga merupakan ibadah kepada Sang Pencipta. Seorang muslim terkadang memiliki kesadaran yang kurang mengenai membayar zakat, sehingga dibutuhkan informasi, pengetahuan dan edukasi mengenai pentingnya membayar zakat. Peran akademisi dan pemerintah sangat dibutuhkan agar sosialisasi dan edukasi mengenai zakat dapat menyadarkan masyarakat untuk membayar zakat.

Pengamatan yang dilakukan oleh peneliti secara langsung dengan menjadi pembicara, menjadikan peneliti mudah untuk dapat mengumpulkan data para responden dan melihat seberapa jauh responden atau peserta kegiatan PKM ini memahami mengenai zakat. Aktifnya para peserta pada kegiatan ini menandakan adanya antusiasme dan keingin tahuan mengenai zakat. Banyak responden yang bertanya dan beberapa kali pembicara memberikan pertanyaan kepada audience dan audience juga antusias untuk menjawab. Keaktifan yang ada, dimana pembicara menerangkan dan audience bertanya merupakan bentuk dari kegiatan pengabdian masyarakat ini sesuai dengan yang diharapkan oleh tim PKM.

Kegiatan PKM ini dirasa masih kurang, pada kegiatan yang akan datang dapat dilakukan sosialisasi den edukasi lebih komprehensif lagi yaitu dengan bentuk pelatihan mengenai zakat, dengan responden lebih banyak lagi, sehingga dapat mencakup masyarakat luas, agar dapat terealisasi potensi zakat yang ada.

\section{KESIMPULAN}

Pentingnya sosialisasi dan edukasi mengenai zakat ini sangat diperlukan karena banyak penelitian yang menyatakan bahwa kesadaran masyarakat akan bertambah dan meningkat tentang zakat dikarenakan adanya informasi, sosialisasi dan edukasi yang didapat. Kesadaran yang ada pada masyarakat untuk membayar zakat sangat membantu dalam merealisasikan pendapatan zakat sehingga dapat memenuhi harapan potensi zakat yang ada. Pendapatan yang besar dari pembayaran zakat dan disinergikan dengan pengelolaannya maka akan dapat mengentaskan kemiskinan.
Kesimpulannya bahwa pemahaman masyarakat yang ada dilingkungan kampus Mega Kuningan Universitas Trisakti tentang zakat semakin meningkat. Antiusias dan aktifnya masyarakat sekitar pada saat pembicara memberikan sosialisasi dan edukasi mengenai zakat dan pengelolaannya, telah dipahami dengan adanya diskusi dan tanya jawab antara peserta dan pembicara.

\section{SARAN}

Pada masa yang akan datang, kegiatan pengabdian kepada masyarakat ini diharapkan akan terus dilaksanakan dan ditingkatkan agar lebih baik lagi dan ditambah lagi oleh model sosialisasi dengan memberikan pelatihan yang lebih comprehensive.

\section{UCAPAN TERIMA KASIH}

Kami ucapkan banyak terima kasih kepada pihak-pihak yang telah membantu terlaksananya PKM Gabungan ini, kepada Yayasan Al-Mughni, masyarakat sekitar Mega Kuningan Jakarta, kepada civitas akademika Universitas Trisakti dan Universitas Esa Unggul. Semoga kegiatan ini dapat bermanfaat bagi kita semua.

\section{REFERENSI}

[1] Worldbank. (2020). Population 2019 Population 2019 (Issue July).

[2] USCIRF. (2017). Indonesia Chapter.

[3] Baydoun, N., Sulaiman, M., Willett, R. J., \& Ibrahim, S. (2018). Principles of Islamic Accounting. Wiley.

[4] BAZNAS. (2018). National Zakat Statistics. Bagian Liaison dan Pelaporan, Baznas.

[5] Jackson, S. (2015). Research Methods: A Modular Approach (5th ed.). Cengage Learning.

[6] Czaja, R. F., Blair, J., \& Blair, E. A. (2014). Designing Surveys (3rd ed.). SAGE Publications.

[7] Merriam, S. B., \& Tisdell, E. J. (2015). Qualitative Research: A Guide to Design and Implementation. Wiley.

[8] Pike, R. W. (2003). Creative 
Training Techniques Handbook: Tips, Tactics, and How-to's for Delivering Effective Training (3rd ed.). HRD Press.

[9] Qaradawi, Y. (2011). Fiqh Al-Zakah A Comprehensive Study of Zakah Regulations and Philosophy in the Light of the Qur'an and Sunna. Islamic Book Trust.

[10] Khan, M., \& Nizami, S. M. (2019). Being British Muslims: Beyond Ethnocentric Religion and Identity Politics. AuthorHouse UK.

[11] Choudhury, M. A. (2019). The Tawhidi Methodological Worldview: A Transdisciplinary Study of Islamic Economics. Springer Singapore.

[12] Karbani, F. (2015). Mastering Islamic Finance: A practical guide to Sharia-compliant banking, investment and insurance. Pearson Education Limited.

[13] Hayeeharasah, F., Sehvises, S., \& Ropha, H. (2013). The Timeline of Zakah. Procedia - Social and Behavioral Sciences, 88, 2-7.

[14] Saad, R. A. J., Wahab, M. S. A., \& Samsudin, M. A. M. (2016). Factors Influencing Business Zakah Compliance Behavior among Moslem Businessmen in Malaysia: A Research Model. Procedia Social and Behavioral Sciences, 219, 654-659.

[15] Arshad, R., Noor, A. H. M., \& Yahya, A. (2015). Human Capital and Islamic-Based Social Impact Model: $\quad$ Small Enterprise Perspective. Procedia Economics and Finance, 31(15), 510-519.

[16] Saad, R. A. J., Aziz, N. M. A., \& Sawandi, N. (2014). Islamic Accountability Framework in the Zakat Funds Management. Procedia - Social and Behavioral Sciences, 164(August), 508-515.

[17] Othman, A. K., Hamzah, M. I., \& Hashim, N. (2014). Conceptualizing the Islamic Personality Model. Procedia Social and Behavioral Sciences, 130, 114-119. 